\section{NOTES ON THE TREATMENT OF PUERPERAL} FEVER.*

BY A. KNYVETT GORDON, B.A., M.B.CANTaB, MEDICAL SUPERINTENDENT, MONSALL FEVER HOSPITAL, MANCHESTER.

THE remarks I am about to make are based on a clinical and bacteriological study of 210 consecutive cases which have come under my care at Monsall Hospital.

\section{Etiology and Pathology.}

Puerperal fever is wound fever. There is always a wound, and there is almays infection of this wound, bat this infection is certainly not always introduced from wlthout, though it is probably necessary that the Infecting agent shall be always directly applied to the raw surface. We do not nowadayg belleve in the production of puerperal sepsls by obscure atmospherlc agencles, such as sewer gas.

First, where is the wound? Well, it is present after every labour at the placental site, and there mas also be some laceration of the cervix which may be due to natural effort or Instrumental interference; also there may be perineal tears. Other things being equal, the seriousness of the wound depends upon its proximity to the fundus of the aterus. Thus, infection of the placentsl site is more likely to give rlse to serlous consequences than a septic laceration of the cervix (apart, that is to sap, from the mechanical effects of such a lesion, which may be considerable); while perineal tears, even if sloughtng, do not usually appear to be of very serious import; in fact, I may say that by themselves they reem seldom to glve rise to systemlc infection.

In normal labour, where there is no interference whatever, there is no reason why infectlon should be carried to the inside of the uterus at all, and, moreover, the placental site is soon sealed by Involution, but directly any external agency' comes on the scene puerperal fever is rendered possible. Thus infection may be carried from without by hands or instruments that are not sterile, or, being sterile, have touched the external genitalis in the process of vaginal examination. When intrauterine manipulations are necesaary, the risk is of course very much greater.

The point, however, that I wish to make in this connexlon is that it is not necessary that the organisms shall be introduced from without. It has been shown by Döderlein and others that the healthy vagina contains, both before and after delivery, certain organisms, amongs whlch are almost always streptococci. As long as the vagins is heslthy its secretion is acid, and these strepto. cocel are saprophytic only, and non-virulent to the patient hersell; in fact, they seem to be beneficlal in that they serve to rid the vagina of such organisms as the $B$. coli which may be accidentally introduced. But 11 by any means these streptococcl reach the interior of the uterue, which is faint]y alkaline and in health always sterile, they become parasitic and virulent.

The Importance of this is that vaginal examinations by aterile hands may carry these harmless vaginal cocel into the uterus, and set up an attack of puerperal sepsis. It is in thls direction that we must look, I think, for the explanation of the cases of puerperal sepsis that occaslonally occur in the practice of the most careful physiclans, and it is a reason for discouraging the making of too frequent examinations by the modern highly-trained obstetric nurse; who is certsinly inclined to err in this respect.

Retention of the placenta, by preventing involution, renders the aterus more liable to infection.

Hitherto I have spoken of partarition infection, which takes place, that is to say, at, or immediately after, delivery. During the puerperinm, however, Infection mas occur even though there has been no manual interference at all. For the explanation of this we must look to two factorsfirst, the use of the vaginal douche, which washes organ. isms, harmless enough in the vagina, into the danger area In the uterus, or agalnst the surface of a cervical tear; and, secondly, to the neglect on the part of the nurse to treat the vulva as the orlfice of a surgical wound, ar $d$ keep it covered untll danger of infection is passed. Of these, the vaginal douche is the more potent factor, * Road before the Altrincham Division of the British Medical Association. especially when it is given with the quite unsterllizable enems ayringe.

When the wound has been infected, we mag have, either :

1. Rapld generalized septicaemla from passege of the organisms direct]y into the veins of the part. This form is usually latal in from twenty. four hours to three days, and the circulating blood is generally found to contsin streptococci.

2. Direct extension through the Fallopian tubes to the peritoneal cavity, and resulting general suppurative peritonitis.

3. Extension as far as the Falloplan tubes only, with formation of adhesions, shuttlng off the general peritoneal cavity, resulting in the occurrence of pyosalplnx, pelvic peritonitis, or tubo-ovarian abscess.

4. Lymphatic extension causipg parametritis, which may go on to suppuration.

The infecting agent is usually a streptococcus, but in the varieties of Infection which occur later on in the puerperium I have more frequently found the $B$. coli commernis. Occasionally the whole fystem becomes invaded with this baclllus as a terminal infection only, and if the case is then seen for the first time, it may be erroneously thought to be the cause of the attack.

\section{Treatment.}

I do not intend dwelling on the prevention of puerperal fever, but it is evident from what we know of the pathology of puerperal infection, that the points to which attention should be directed are :

1. The avoidance of anything that mas interfere with the closing of the placental site, wuch as the retention of placental tissue in utero.

2. Care should be taken that no other wound be made; here I cannot but think (Irom what I have seen) that the harm that mas result from the application of forceps before the os is dilated is not, as a rule, sufficlently well recognized. I have seen, inter alia, lacerations of the vagina so extensive that the perlosteum was stripped from the publc bone below, while the upper part of the tear had laid open the peritoneal cavity, so that the intestine protruded into the vagina. Apart from euch an exireme case as this, I may say that of the cases under my care in which infection took place at the confinement and forceps had been used, no less than 80 per cent. had diagonal laceration of the cervix, which appeared to be the source of the infection for whlch ther were admilted.

3. We should endesvour to avold the infection of the wound by abstention from too frequent vaginal examinations and by the wearing of subber gloves when ang manipulations are necessary.

4. There can, I think, be little doubt that douching the vagina is seldom necessary and always risky, and that it should never be performed with a rubber springe.

5. The valva should be kept covered with an antlseptic: pad of sublimated wood wool or similar material.

Now that we have cleared the ground a little by these prellminary considerations, we come to the actual treatment of puerperal infection when it has occurred. Here we are brought face to face with the fact that the practice on this 'point differs widely in different countries, and even in different clinles in the same country. It is difficult to reconclle the utterances of the varlous anthoritles, and no via media seems to be possible.

It is important in any case not to lose sight of the fact that each patient must be treated on the Information obtained from careful examination, and I do not know of any disease in which a thorough physical exploration of every accessible organ is so important as it is in puerperal fever. I do not think it is possible to use the term. "routine treatment" at all in so complex and so tatal a dis ease as puerperal lever.

However, we may gay that there are two main schools of teaching-the active and the passive. Those who counsel the minimum of interference do so in the bellef that between the organisms and the host lles a barrier of leucocytes which it is important to leave intact, and not destroy by any active local disinfection. This barrier is stated to exlst either in the uterine muscle and, according to later teaching, in the inflammatory thickeninge round the uterus also. In the latter case it is difficult to see how disinfection of the uterus can have any mechanlcal action on it. 
Those who prefer active local treatment, however, hold that when puerperal fever is established, the barrier of leucocytes is proved, ipso facto, to be Ineffective, and that the best course is to remove the micro-organisms in so far as they are accessible, even if it involves the removal of part of the barrier wall as well.

For both of these views there 18 a good deal to be said, eapecially in theory, but it is an unfortunate fact that the literature of puerperal fever abounds in statements that have been made about purely cllnical features by authors whose experlence of the disease has been limited to the examination of cultures and histological sections. Perhaps it is In consequence of thls that many clinicians of ripe experlence have looked with undue disfavour on the emanations from the pathologlcal laboratorles.

The treatment of puerperal fever has also suffered, like many other departments of medicine, from the splrit of compromise which has shown itself in the common practice of attempting to comblne both the active and the passive methods in the individual case, with the result that the uterus is neither left alone nor adequately disinfeeted. Concessions to the passive school are made by the administration of small doses of quinine Internally, while a surgical aspect is added by the use of the intraaterine douche, and possibly by the removal of any large masses of retained placenta by the finger or the blunt curette. I do not, myself; belleve that the uterine wall can be disinfected, or its contalned organisms hindered in thelr growth by playing apon it with any chemical whatsoever that it is sale to $u$ se In the quantlty required, and I have seen, not once only but again and again, general peritonitis set up by the practice of intrauterine douching. I think we may say definitely that whatever chemical be used for the uterine wall should be supplled with a swab, and not with the douche, If a Higglnson's syringe be used for the latter the practice becomes indefensible.

For the passive method pure and aimple there is something to be sald, and I quite admit that many cases recover well on antlstrep fococcic serum and varlous drugs and stimulants Internally without any local interlerence at all. But this method is not, I submit, universally applicable. It Is, I think, very largely a matter of the severity of the case and the time that has elapsed before the patient is first seen or the diagnosis of puerperal infection made.

My own experlence has been almost confined to very severe cases. I do not see the early cases at all, the average day of disease on admission to Monsall Fever Hospital being between the filth and the sixth.

When I first began to see these $I$ was Impressed by what I had learnt from textbooks and so on, and, moreover, had been taught that any actlve Interference with the puerperal uterus when once it had become infected was tantamount to signing the death certificate, but I had heen accustomed to use the intranterine douche. Out of 79 cases treated in thls way, with or without serum, 37 died, a mortallty of 46 per cent. I am uniortunately not able to say in what proportion of these intraterine douching was employed, but it was at least 70 per cent.

These results were not encouraging, and I accordingly began to doubt the protectlve capacity of the granulation wall. What remnants of faith I still possessed were disslpated by the fallure to discover the existence of the wall at all In a large number of sections taken from severe cases of puerperal sepsis that had not recelved active local treatment. So I commenced the use of the sharp curette, followed by 8 wabbing of the raw surface with strongly bactericidal chemicals. After some trla]s, I fixed on undiluted izal flald as the most sultable application, In that it had for streptococel a very hlgh germicidal coefficlent as compared with the phenol standard, and I had found it to be non-toxic. I have used this now for ebout five years.

The detalls of the method are as follows. A general anaesthetlc is not glven, but one hour prevlous to the operation a dose of brandy (usually $2 \mathrm{oz}$ ) dlsgulsed with Ilquid extract of llquorice and hot water is administered and half an hour later a hypodermic injection of morphine -usually $\frac{t}{4}$ grain. The vaglna is cleansed and packed with a swab soaked in 5 per cent. solution of cocaine. When the patient is somnolent, she is placed in the Ilthotomy position and the cervix exposed and steadled with volsellae. Caltures are then taken (with a sterile cwab) for bacteriological examination. After digital exploration of as much of the Interior of the uterus as may be accesslble, the endometrium is removed completely down to the muscle with a light sharp curette, having its extremity shaped like a hoop, with a broad flattened end. Perforation of even a friable uterus with this instrament is proctically impossible.

The curette is then laid aside and the raw surface gone over very thoroughly and firmly with swabs soaked in the undiluted izal fluid. The uterine cavity is then packed with izal gauze and a tampon inserted in the posterior cul.de-sac. These plugs are withdrawn in twenty-four hours and are usually not replaced. No. douching of any kind is given at the operation or subsequently. If the uterine discharge again becomes foul the swabblng with iz $3 l$ is repeated, and the uterus again plogged.

In a further series of 129 cases treated in this way, the mortality has been 24 per cent. only, though the type of case admitted to Monsall has not changed, nor have any alterations occurred in the methods of general medlcation or of nursing.

Now thls redustion in mortallty is somewhat striking. and it does not at all events support the opinion that active local interference must be entlrely condemed, as so many would have us believe.

I should add (though there is nothing special in this) that all collectlons of pus, wherever they may be in the pelvis, have been opened either vaginally or by abdominal gection whenever they have been dlagnosed with certainty, and sometimes by a purely exploratory incision. Patlents admitted with general peritonitls have been treated by laparotomy and drainage. Of these I have now had 13 consecutive cases with 8 recoverles. Flushing was resorted to in one case only, the others being treated (apart from free drainage) by propplng up in the sitting position, combined with copious rectal or subcutaneous infusions of normal saline solution.

But there is another side to the question. I have seen the severe cases only, and perhaps I am not in a position to say very much abjut the mild or early cases. But Inasmuch as almost all my own patients had been treated by intranterine douches and quinine only until they were very nearly morlbund, it is reasonable to infer that these methods are not the best, even if used early, especially as the statement was very frequently made by the practitioner that he did not regard the case as a severe one at first. We must, I repeat, condemn the douche.

I would, then, say that I cannot mysell see why mild and early cases should not be treated by the eharp curette and the swabblng; but at all events the swabbing alone with the izal or other rellable antiseptic can do no harm even to our friend the granulation wall. It is curiong, iccldentally, to see how the nature of thls structore changes. If it be enggested that the aterus should be disinfected, the wall is sald to be delicate and fragile, so that we must take care not to hurt it; but at times it springs up to renewed vitality, and is then described as Nature's strongest line of defence.

I would suggest, then, that when, during the puerperium, a rise of temperature occurs for which there is no extragenital cause to be found, in addition to the very useful 5 grains of calomel and sallne purge which are usually given, the uterus should be mopped out with several swabs wet with the undiluted izal, and that if this is not effectual, then the sharp curette should be used, followed again by careful swabblng. Mach of the condemnation with which the curette has been visited bas been just]y earned, and is due to the fact that the 1 aw surface has not subsequently been adequately disinfected. To carette alone is certainly worse than to do nothing; to curette and douche is worst of all. I have not mentioned either the blunt or the flushing curettes because they are not weapons of precision and thelr use requires force. and 18, therelore, dangerous. It is also a little difficult to sfe how the much-recommended process of exploration with the finger is carried out in the puerperal uterus. I have almost Invariably found the Inndus and cornus ont of reach-in fant, it is no uncommon thing for the cavity to measure 6,7 , or even $8 \mathrm{in}$. In length. It is difficult to take the advocates of digital manipulation in puerperal tever seriously.

I have perforce confined myself mainly to the detalls of local treatment, as I believe this to be the most important point. In the treatment of the septicaemic symptoms 
themselves there is, in my opinion, nothing to equal large quantities of sterilized saline solution given per rectum or eubcutaneously. With these we may combine calomel and alcohol, both in fairly large doses. Antipgretic drugs zre usually harmlul. We do not usually need to treat the pyrexis per se, and, If we do, cold water is the best and bafest remedy, used either in the form of a bath or cold sponging.

Antistreptococcic serum, I would say, is useful in a limited number of cases only, though probably never harmful.

I have given now a tairly large number of different merums, and time will not permit of discussing this question as 1ts Importance deserves. Briefly, the serum should be polyvalent-that is to say, prepared from many strains of streptococcl, some of which should have been obtained from cases of puerperal fever. At least $50 \mathrm{c.cm}$. should be given subcutaneously, and $100 \mathrm{c.cm}$. are preferable. The dose should certalnly not be repeated, ss from so dolng joint pains and pyrexis are apt to result.

The type of case in which these bactericldal serums are of benefit is that in which the streptococel are present in the circulating blood. I have never been able to satisfy myself that they affect the local lesion at all, and their value in checking absorption of toxins from the lesion is at least problematical. They are not supposed to have antitoxic value. For myself, I now give them only in casses where the septicaemlc symptoms are severe and no local lesion can be found to account for the intensity of the Illness.

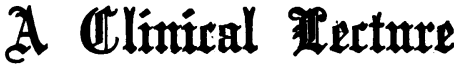

\section{THE DIAGNOSIS AND TREATMENT OF RENAL MOBILITY.}

Dheiphred at the Medicat Graddates' College asd PoLYCLINIC.

By GILBERT BARLING, M.B., F.R.C.S., PROFESSOR OF SURGERY IN THE UNIVERSITY OF BIRMINGEAM, SURGEON TO THE GENERAL HOSPITAL.

MovabLE kidney is a condition which has, during the last few years, become the subject of much discussion, and opinion appears still to be divided upon several points in connexion with it. Is it of Irequent occurrence? Is it responsible for the symptoms often assoclated with the mobllity, or are these merely colncldent? By what means can the mobllity best be combated ? Is firation of the organ followed by relief to the symptoms complained of? These and some other points I propose to address myself to this afternoon. In the first place, let me point out that in the healthy living body the kidney is not an absolutely fixed organ; I mentlon this because In one of the best modern textbooks of medicine I notice it so described. When operating on the abdomen for other conditions I have had many opportunitles of handling the kldneys, and find that both organs may be easily displaced downwards for an Inch to an Inch and a halt. We have, then, In the condition known clinically as "movable kidney," simply an exaggeration of a normal condition, induced probably by loss of abdominal fat, by lax abdominal walls, occasionally by actual violence, influenced also probably by the lumbar pouches being more shallow in some individuals than in others.

Signs aND SYMPTOMS.

Ot the frequency of undue mobllity there should be no doubt; it is common in women, comparatively uncommon in men, though by no means rare in the male. Its detecton is generally quite easy with proper method In examination. The patient should first be examined lying on the back in such a way as to produce muscular relaxation. The left hand is used to investigate the right side, the right hand to Investlgate the left side, the palm of the hand being pressed firmly against the lumbar muscles Immediately below the last rib, the thumb lying on the front of the abdomen, close to the costal arch, so that the hand can grasp the patient's side. The patlent is now told to take two or three deep Insplrations, and at the second or third effort, whilst the paim puisies firmly up from the baet, the thumb follows the retreating abdominal muscies at the beginning of explration, and when the explratory act is completed, if the kidney is movable, it may be lound elther in the gracp? of the examining hand, or quite below it, and palpable bj the hand whtch has hitherto not been concerned in the examination. Il the kidney is not detected in this way a bimannal examination shonld be made in the semiprone and in the knee-elbow positions. Finally, the condition of the kldnes should be Investigated in the upright posltion, one hand pressing firmly into the loin from the back, the other belng used on the front of the abdomen, the patient leaning slightly forwards and resting the hand of the side under examination upon some support. It is Important to examine in thls position, because there are some kidneys which do not reveal thelr displacement until the patient is vertical; or if the kidney is already lound to be displaced downwards in one of the prevlens examinations, It will generally be found to come lower. down when the patient is in the vertical position.

The kldney having been recognized will, when allowed to do so, often shoot back into the loin with a sllp which is absolutely unmistakable, or It can alternatively be gently alid back beneath the costal arch. If the patlent has been recumbent for some time mobility of the kidney is likely to be detected only on examination in the vertical position.

I have passed briefly over these less controversial points, but when I come to consider the symptoms complained of by patients with undue renal mobllity I am upon less certain ground, and may fall to carry agreement with what I have to say. That such patlents complain of many things is notorious; the real point at lasue is whether the troubles complained of are due to the movable kldney, are merely colncldent with it, or whether the symptoms complained of and the mobllity of the kidney are both due to some common factor, such as gastroptosls, the stomach dragging down the kidney as it descends.

The symptom complained of most commonly, I think. Is tiredness from insdequate canse, whether from phrsica) or from mental work. Worse than the simple exertion of walking in some patlents is standing about, whether at the wash-tub or at some social function. If pressed to explain why they get so tired, many patients attribute this to dragging and discomfort in the back on one or both sides. Exertion, such as is involved in stooplng or in plaping ganies such as golf, occasionally produces marked discomfort, amounting it may be to pain, and have known riding also cause pain which is of a slckening character in women who hunt, though a feeling of complete exhanstion the same evening, and for $a$ day or two after, is more often complained of than actual physical pain. Several of my cases have complained of the discomfort they experlence when in bed if they turn to the gide opposite to the moblle organ. Occasionally thilg produces a feellng of rather severe nausea; and if both. kdneys are mobile, comforkable rest is only obtained when the patient lies on the back. Indigestion is a common trouble, pain coming on at irregular intervalis after food, It may be independent of the nature of the lood: flatulence is often associated. Suspicion of gastric ulcer may be excited, especially if the patlent vomits from time to time. But ulcer and stenosis are generally excluded by the erratic nature of the symptoms, the absence of a fixed polnt of tenderness, the absence of stasis. The stomach will often be found proptosed and with atonlc dilatation; and we may have the converse-marked gastroptosis and dilatation with nephroptosis.

Ag an uncommon condition we meet with attacks of renal pain so severe and so colic-llke in nature as to suggest a diagnosis of calculus, blood in considerable quantity and pus may be found in the urine, the kidney may be very tender on palpation, vomiting may be persistent, and frequent micturition completes the picture. Such a case has been under my care during the last few months, a lady sent to me by Dr. Faulkner of Banbury. The symptoms had troubled the patient intermittentis for twelve years; both kidneys were movable, but the principal symptoms implicated only the left side. Renal atone recently impacted in the ureter of a movdble kidney geemed the appropriate diagnosis, but it was not confirmed by radlography. Exploration, which involved the opening of the kidney for digital examination and the passage of a bougie down the ureter, showed conclusively the absence of stonte. $A$ considerable degree of dilatation of thescalyees 